\title{
THE SPIRITUAL MEANING OF SULUK IN SYI'IR TANPA WATON
}

\author{
Siti Maslahah \\ UIN Sunan Kalijaga \\ maslakhahsiti6@gmail.com
}

\begin{abstract}
:
Syi'ir Tanpa Waton, a work of KH Mohammad Nizam As-shofa, is a sufi poem. It is a cultural endeavor to response the modern problems of Muslims who easily judge others infidels without realizing their own infidelity. This poem is used as a closing recitation of Reboan Agung (Islamic regular study forum of Muslim conducted in every Wednesday night learning the book of Jamī' al-ușul fi al-uliyā' the work of Shaykh Ahmad Dhiya 'uddin Musthofa Al-Kamisykhonawi) and the book of Al-Fath urrabbani wa al-Faidurrahmani the work of Shaykh Abdul Qadir al-Jilani. The forum took place at Islamic boarding school of Ahlus-Shofa Wal Wafa Sidoarjo, East Java. This research is inspired by spiritual emptiness caused by the modernization and the shallow understanding of Islamic teachings. Islam is studied and practiced at the level of shari'a without deepening it into higher stages of sufism i.e. tariqa, haqiqa and even marifa. This study employs content analysis and qualitative approach aims at analyzing the message or moral values contained in the literature. Then, I classifies basic thoughts into some themes and selects these themes to find the central idea of the text. Substantively, the verses were structurely written ranging from understanding comprehensively the teachings of Islam, teachings self-awareness, the teachings of social piety (humanism) and the teachings of Sufism namely suluk practice. Suluk in Syi'ir Tanpa Waton is devided into two parts, namely: small suluk (khalwat fi alkhalwat) and big suluk (khalwat fi al-jalwat). Meanwhile, suluk nafs/soul purification and suluk Qalb/heart purification are called takhalli/purgativa. In addition to that, sirr emptying (tahalli/contemplative) followed by soul enlightening (Tajalli/Illuminativa) is a chain of process or stages that should be passed in the form of small and big suluk which take place in suluk Qalb (takhalli/purgativa) and sirr emptying (tahalli/contemplative). Suluk in the present context is urgently needed for peaceful soul to face negative effects of modernization and spiritual crisis of modern human by doing seclusion physically and mentally (qalb/jasad) from the crowd of human life. Seclusion is a symbol of taqarrub ilallāh by self-equipping with spiritual values to depend on nothing but Allah. This process will consruct oneself to be calm, patient, active, productive, firmly independent, consistent, having integrity and good personality.
\end{abstract}

Keywords: Syi'ir Tanpa Waton, Suluk, Spiritual Meaning 


\section{A. Introduction}

$\mathrm{T}$ oday's technological and industrial advances make humans' lives easy. On the other hand, modernity also brings negative impacts on life. One tangible indicator is the growth of moral decadence, the tendency of people to think pragmatically, materialistically and consumeristically, the fragility of social solidarity, the lost of human values and the lack of religious awareness. ${ }^{1}$

For those modern human problems, Husein Nasr offered an alternative that is to explore and practice Sufism. Sufism is the answer to human spiritual needs. In the view of Sufism, the resolution and improvement of the situation cannot be achieved optimally if only sought in the physical life. Improvement can only be gained through the three main forces in human, i.e intellectual, lust, and anger faculties. If all three are balanced, human life will be normal. ${ }^{2}$

Sufism is a method of spiritual training in the form of an effort to get closer to Allah. Besides, sufism is a manifestation of religious morals. Siroj said that sufism is a huminitarian mission to complete Islamic mission holistically from the dimension of Islam, Iman, and Ihsan. Siroj added that the essence of sufism is inseparable from human's personality which consists of two elements namely humans as God's material creation and human as khuluq, as God's immaterial creation. Doing Sufism then means to perfect human spirituality. The perfection here means to get as close as possible to Allah. ${ }^{3}$

Meanwhile, tarekat means a way or direction of performing rituals/ibadah in accordance with the example that was practiced by the prophet Muhammad and his companions, successors of the companions (Tabi'in), and the generation after the successors (Tabi'it-Tabi'in), down to muslims scholars, and to us now. ${ }^{4}$

Martin van Bruinessen said that tarekat is the last stage of the sufism development. Sufism is the knowledge, tarekat is the method implementing the knowledge, meanwhile suluk is the implementation and dzikrullah (remembering Allah) is the content. ${ }^{5}$

Afterwards, Nasr said that to understand the inner dimension of Islam as contained in tarekat and explained by hakikat, one must move to the forerunner of Islamic art. This dimension has to be connected to Islamic spirituality. The term

Panitia PIBSI XXIII UAD, Bahasa dan Sastra Indonesia Menuju Transformasi Sosial Budaya Abad XXI, (Yogyakarta: Gama Media, 2002). hlm. 505.

2 H. M. Amin Syukur, Menggugat Tasawuf, (Yogyakarta: Pustaka Pelajar, 2012), hlm. 113-114.

3 S. A. Siroj, Tasawuf Sebagai Kritik Sosial, (Bandung:Mizan, 2006), hlm. 92.

4 Mustafa Zahri, Kunci Memahami Ilmu Tasawuf, (Surabaya: Bina Ilmu, 1973, hlm. 56.

5 Muhammad Ali Akbar, Studi Tentang Suluk Dalam Tarekat Naqsyabandiyah Khalidiyah Aminiyah, hlm. 5 . 
"spirituality" in the language of Islam is associated to the word ruh or soul referring to spirit or meaning. Those, these terms refer to inner matters and interiority (inner dimensions of Islamic tradition) so that one must seek the forerunner of Islamic arts and the forces creating or sustaining it so that Islamic art can have its wholeness. ${ }^{6}$

Syiiran or javanese poem is a form of Javanese tradition or local tradition which is modified into Islamic teaching. The word syiir comes from Arabic word "syu'ur" which means feeling. 'The formation of syi'iran gives meaning that contains messages from the author. Furthermore, the maning also can function as norms or values in a society. Syiiran can also function as a means to spread Islamic teachings to society. Aesthetic nuance of the literature and the meaning contained in syi'iran can attract attention of the society so that the messages in it can be more easily understood. Even, the syi'iran tradition has extraordinary dogmatic function since it contains information about cultural values that are realized by religious values.

One of syiiran that contains relgious values is Syi'ir Tanpa Waton. The syi'ir which becomes the object of this research is written by K. H. Muh. Nizam As-Shofa, the director of the Islamic Boarding School of Ahlus-shofa Wal Wafa Simoketawang Wonoayu Sidoarjo, East Java. Many thought that Syi 'ir Tanpa Waton was the work of (late) Gus Dur, whereas in fact the Syi ' ir had existed long before Gus Dur popularized it; since 2004 to be precise. ${ }^{8}$

Syi'ir Tanpa Waton is a distinctive feature of Javanese poetic Sufism which uses a lot of uptake from Arabic and Kawi language which contains an invitation to understand Islam comprehensively from the approach of Sufism with the four phases of Maqamat (stations) namely: shari'a, tarekat, haqiqat, and makrifat. ${ }^{9}$

Syi'ir Tanpa Waton is relevant to the current era because Islam which is perceived lately is the formalist Islam that emphasizes only on the surface aspect (sharia) without paying attention to the esoteric depth of Islam (tarekat, hakikat, and makrifat). The awareness on the values of life that are created by human cannot overcome the negative effects of modernization. The divine revelation is the source of the guidance of life essential values. One of the efforts made to explore the values of life that comes from Divine revelation is to undergo the act of suluk. For this reason, the author will examine suluk in Syi'ir Tanpa Waton as one of an alternative effort or academic resolutions to evercome the problems mentioned above.

6 Sayyid Husein Nasr, Spiritualitas dan Seni Islam, terj. Sutejo, (Bandung: Mizan, 1993), p. 16.

7 Sugeng Sugiono, Bunga Rampai Bahasa Sastra dan Kebudayaan Islam, (Yogyakarta: Fakultas Adab IAIN Sunan Kalijaga, 1993), p. 76.

8 Erfandi Putra, Syi'ir Tanpa Waton dan Sejarahnya, As-Shofa, 25 Desember 2015-2 Maret 2016, p. 17.

9 Ahmad Shofi Muhyiddin, Syiir Tanpa Waton Al-Maghfurlah K. H. Abdurrahman Wahid (Gus Dur), (Yogyakarta: 2015)

Teosofia: Indonesian Journal of Islamic Mysticism, Vol. 7, No. 2, 2018 


\section{B. Discussions}

Based on the background elaborated above, the author is going to discuss the meaning contained in the Syi'ir Tanpa Waton, how the suluk in Shi'ir Tanpo Waton is and its relevance for the present context.

\section{Profile of Syi'ir Tanpa Waton(STW)}

\section{a) Author and Pesantren ASW (Ahus-Shofa Wal-Wafa)}

The syi'ir is written by K. H. Mohammad Nizam Ash-Shofa or well known as Gus Nizam. He was born in Sidoarjo 23 October 1973, the third son of $\mathrm{Hj}$. Siti Maryam and K.H. Ahmad Saiful Huda. He started his education at Islamic Elementary School (Madrasah Ibtidaiyyah/MI) Bahrul Ulum Krian, State Islamic Junior High School (MTsN) Krian and at the same time he stayed at Pesantren Darul Falah under the supervision of Kyai Iskandar Umar Abdul Latif. He then moved to Lirboyo and studied there for around 1.5 year. He also once learned Ilamic knowledge in Aceh for two years. After that, Gus Nizam chose to stay at Islamic Boarding School (Pesantren) AlNur El-Kasyaf in Bekasi with the supervision of K.H. Dawam Anwar. Here he studied tarekat before he left for Cairo. He continued his study until smester 8 at STAI Salahuddin Al-Ayyubi majoring Arabic Literature. At the 8the smester, Gus Nizam was granted a scholarship to study at Cairo, Egypt. There he studied Arabic Language, and tarikat. K. H. Mohmmad Nizam As-Shofa, Lc., is the grandson of a mursyid teacher Hadratus-Shaykh al-Mukarrom KH . Sahlan Thalib, Krian Sidoarjo. ${ }^{10}$

In 2002, he started an Islamic study forum to learn sufism every Wednesday night at 09.00 PM in Tegal Tanggul Wonoayu. Thousands of learners, male and female studied in this forum. The book studied was Jamī' al-ușul fi al-uliyā' the work of Syaikh Ahmad Dhiya'uddin Musthofa Al-Kamisykhonawi and Al-Fath urrabbani wa alFaid urrahmani written by Syaikh Abdul Qadir Al-Jilani. These two books are the main sources for practitioners of tarekat Naqsabandiyah Khalidiyah Mujaddidiyah. ${ }^{11}$

Martin Van Bruenassen, an anthropologist, believes that tarekat Naqsabandiyah is the largest tarekat congregation in Indonesia. In its history, this tarekat was separated into three groups, including the Naqsabandiyah Khalidiyah, Naqsabandiyah Mazariyah, and Naqsabandiyah Mujaddidiyah. ${ }^{12}$

On the other hand, most local clerics and religious scholars strongly opposed the study forum and considered it heretical. At the beginning of the study forum,

10 Erfandi Putra, Tasawuf Nafas Dakwah Gus Nizam, As-Shofa, p.9.

11 Interview with Abdul Wahab Machfudz, Khalifah (Guz Nizam’ Vice) at Ponpes Ahlus Shofa Wal Wafa Sidoarjo on 18 May 2016.

12 Martin Van Bruinessen, Tarekat Naqsabandiyah di Indonesia Survei Historis, Geografis Dan Sosiologis), p. 65-69. 
almost all the participants were hoodlums and "naughty" children who were street children. They still lack of Islamic knowledge. They often even drank alcohol and did not perform compulsory prayers. The clothes they wear are perfunctory and look messy. Perhaps seeing this condition, many clerics and religious teachers considered the teachings studied in the forum as heretical. In addition, ASW often accepted people with mental illness such as crazy or a trance (a spirit-possessed man) to be treated for three to four years. ${ }^{13}$

Gus Nizam's exemplary attracted society of various areas to learn Islam from him. Up to now, there are approximately 5.000 people from various study background at Pesantren Ahus-Shofa Wal-Wafa (ASW), 28 of them stay at Pesantren and the others go and forth from several cities in East Java. ${ }^{14}$

\section{b) Controversy of Syi'ir Tanpa Waton}

At first, Guz Nizam created this syi'ir as a closing recitation in the Islamic study forum in Pesantren Ahlus-Shofa Wal-Wafa which was conducted every Wednesday night. This syi'ir was inspired by the sadness of the author seeing many radical and hardliner Islam organizations showing violance and easily accusing others heathen without self-reflection. In addition, the author of this syi'ir was inspired by nowadays muslim clerics (Kiai) and scholars (Ulama) whose quality of sincerity, seriousness, wira' $i$ (the behaviour of not letting heart depend on wealth and worldly life) are far different from that of the companions of the prophet. This situation inspired the author to write poem in Javanese language because the author is fond of javanese puppet and language. The content is based on what he learned from his sufism teacher. ${ }^{15}$

Most people assume that this syi' ir is the work of Gus Dur since his singing the syiir was recorded widely spread out among society. It found its moment to be more familiar in 2009 when Gus Dur passed away. Whereas, the syi'ir existed in 2004 and was always sung after studying Jami'ul Ushul and Alfathur Rabbani every Thursday night. ${ }^{16}$

This syi'ir became famous when Imam Nahrawi asked support and vote for his candidacy of Indonesian parliamant member representing Sidoarjo city, East Java. At that time, he joined the study forum in Ahlus-shofa Wal Wafa. As the closing song

13 Interview with Abdul Wahab Machfudz, Khalifah (Guz Nizam' Vice) at Ponpes Ahlus Shofa Wal Wafa Sidoarjo on 18 May 2016.

14 Fahrur Roziq, Pondok Pesantren Ahlus-Shofa Wal Wafa Pengkaderan Dunia Akherat, As-Shofa 25 Desember 2015-2 Maret 2016, p.29.

15 Interview with Abdul Wahab Machfudz, Khalifah (Guz Nizam' Vice) at Ponpes Ahlus Shofa Wal Wafa Sidoarjo on 18 May 2016.

16 Interview with Muhammad Nizam Assofa, Khalifah (director) at Ponpes Ahlus Shofa Wal Wafa Sidoarjo on 18 May 2016.

Teosofia: Indonesian Journal of Islamic Mysticism, Vol. 7, No. 2, 2018 
"Syi'ir Tanpa Waton" was sung together, he was touched and cried. Then, he requested to copy the song and launched it as Syi'iran Gus Dur. This was the beginning of the confusion. ${ }^{17}$

The chairman of Nahdhotul Ulama branch Malang City, K. H. Marzuki Mustamar, suggested his congregation in Great Mosque of Malang to duplicate the disk of Syi'ir Tanpa Waton and entitle it "Gus Dur' Poetry". He also suggested the followers of Nahdlotul Ulama' to recite it in religious ceremonies such as tahlilan, tasyakuran, Laylatul Ijtima', and in NU organizational meetings, etc.. This command was followed by almost all Nahdlotul Ulama's members in Surabaya. ${ }^{18}$ From there, people started to think that the poem belonged to Gusdur. This opinion quickly spread out until Malang City, and East Java. ${ }^{19}$

The author of this syi'ir said that he had no problem with this situation. Instead, he was grateful for creating a syi'ir or poem that can be heard by a wider community. But, some of his Jama'ah or congregation who were lawyers did not like it when the Syi'ir was associated to others, so that they registered to the Director General for Intellectual Property Rights (IPR) for a copyright. ${ }^{20}$

\section{Analysis on the Meaning of Syi'ir Tanpa Waton}

Syi'ir Tanpa Waton (STW) has explicit and implied meanings. There are many advices related to people's lelakon (behavior) towards hisself, others and his God.

\section{a) Doctrine of Not Accusing Others Infidels}

This verse contains author's advice and concerns for Muslims in this day and age. Many muslims, in reality, memorized the Qur'an and Hadith of the Prophet, but they are easy to judge others infidels. This is because of the fact that studying shari'a only can make muslim hard-hearted and easy to judge other groups who have different understandings in terms of social, culture, and interpretation of the Qur'an.

\section{Akeh kang apal Al-Qur'ān haditse \\ Seneng ngafirke marang liyane \\ Kafire dewe dak di gatekke \\ Yen isih kotor ati akale \\ Meaning:}

17 Asal usul Syiir Tanpo Waton K. H. Nizam As-Shofa di anggap Syi'iran Gus Dur. https://www.youtube.com/watch?v=7tHr8MwXeBY accessed on April 10, 2016.

18 Asal usul Syiir Tanpo Waton K. H. Nizam As-Shofa di anggap Syi'iran Gus Dur. https://www.youtube.com/watch?v=7tHr8MwXeBY accessed on April 10, 2016.

19 Asal usul Syiir Tanpo Waton K. H. Nizam As-Shofa di anggap Syi'iran Gus Dur. https://www.youtube.com/watch?v=7tHr8MwXeBY accessed on April 10, 2016.

20 Syi'ir Tanpo Waton 1 - KH Moh Nizam As-Shofa di TV9 https://www.youtube.com/watch?v=Hufp6gKUZM accessed on April 10, 2016. 


\title{
Many (muslims) memorized the Qur'an and Hadith But still accuse others infidels They will never notice their own infidelity if their heart and mind are still dirty
}

An accusation of infidelity can endanger ukhuwah Islamiyah or Muslims botherhood. It can also cause the most severe result that is the emergence of division and animosity among Muslims. Ijtihadi or furu'iyah matters are not axiomatic, therefore differences of opinion on those matters are not undeniable and must be addressed wisely with tasamuh (high tolerance), friendly behaviour and ukhuwah Islamiyah .

Mã zann akhauka akhiran fahua kā fir means that we must not judge others since if we see negative side of something without examining and thinking more deeply about it, it is, in fact, the negativity of ourselves. If our behavior is bad, then our prejudice will also be bad, İāa sā'a fi'lul ma'ri sā 'a kulluh. Prejudice happens because the intentions at our hearts are not good. As a syi'ir or poem, the work of Abut Thoiyib, said; if a man's behavior is bad, his heart's prejudice is also bad. ${ }^{21}$ According to this author, those who have bad prejudice are considered not able to restrain and control his desires. His heart is still impure and his intellect cannot understand the message of the Qur'ān and Hadith.

STW teaches us to do self reflection, investigating deeply into ourselves, giving more attention to any forms of disbelief in ourselves. This message is reflected in the verse "kafire dewe gak digatekke", our own infidelity is unnoticed. The phrase "kafire dewe" emphasizes the importance of self-awareness, reflecting on oneself to focus on the "our own selves' household", so that our heart's and mind's uncleanness is exposed as stated in the syi'ir " yen iseh kotor ati akale"meaning if one's heart and mind are still dirty.

\author{
Kelawan kanco dulur lan tonggo \\ Kang podo rukun ojo daksio \\ Iku sunahe Rosul kang mulyo \\ Nabi Muhammad panutan kito \\ Meaning: \\ To friends, relatives, and neighbors \\ Get along well, don't waste it \\ That is the tradition of the noble Rasul \\ Prophet Muhammad is our role model
}

21 Syi'ir Tanpo Waton 2-KH Moh Nizam As-Shofa di TV9

https://www.youtube.com/watch?v=eDdCnF6c4WA accessed on April 10, 2016.

Teosofia: Indonesian Journal of Islamic Mysticism, Vol. 7, No. 2, 2018 
The syi'iran stated iku sunnahe Rasul kang mulyo, Nabi Muhammad panutan kito. The things taught in the syi'ir were sunnah or the tradition of the Prophet, the role model of good behavior. Thus, following the sunnah of the Prophet must strengthen the firmness of the acts to build harmony and prevent and avoid persecution. Those are signs of righteous people.

\title{
b) Riyadhah, Tarekat, Zikir and Suluk
}

Piousity is the clarity of the heart, which is obtained by knowledge. Meanwhile, the behavior of the tarekat (Sufism) and makrifat (trully knowing oneself) is reflected in everything that is spoken and that is done. Meanwhile, the hakikat is established in the heart.

\author{
Kang aran sholeh bagus atine \\ Kerono mapan sari ngelmune \\ Laku thoreqot lan ma'rifate \\ Ugo hakekot manjing rasane \\ Meaning: \\ What is called Sholih (piousity) is the state of good heart \\ Because of settled knowledge, \\ doing thoriqot and makrifat \\ and the also hakikat in order to get the taste (of haqiqat)
}

Here the author invites the reader to become a pious generation that is to be a wise person who is able to internalize and apply the teachings of Islam as a whole, namely sharia, tarekat, makrifat and hakikat. Studying all of them creates strong faith and tauhid. It is not easy for us to judge other groups as infidel.

The journey from one station (maqam) to the next one is long, heavy and difficult. One of the mujahadah methods that are commonly done are through riadhah or training namely dhikr and suluk. The STW mentioned jo nganti lali (don't ever forget) which means that the methods are carried out intensively and continuously.

Muslims scholars argue that tarekat is the road taken by being carefull when performing worhip. One does not easily take rukhsah (dispensation in prayers) in worships although they actually are allowed to do the rukhsah. He or she is more carefull in performing prayers. ${ }^{22}$

Kang anglakoni sakabehane

Allah kang bakal ngangkat derajate

Senajan asor toto dhohire

22 Edy Yusuf Nur, Mengali Tasawuf yang Hakiki, (Yogyakarta:Suka Press, 2014), p. 24 


\section{Ananging mulyo maqom drajate \\ Meaning: \\ Let's do everything \\ Allah will lift our degree (maqam) \\ Although we look ugly in appearence \\ But (we are) noble in (maqam) degree}

The above verse is the core of the poem, let's do everything, Allah will lift our degree (maqam), although we look ugly in appearence, but (we are) noble in (maqam) degree. Allah will lift those people doing such deed into the highest degree and will place them in the most noble place beside Him and when died, Allah will welcome them and get them in His heaven.

\section{Lamun palastro ing pungkasane \\ Ora kesasar roh lan sukmane \\ Den gadang Allah swargo manggone \\ Utuh mayite ugo ulese \\ Meaning: \\ So in the end \\ Our spirit and soul do not get lost \\ God promised us heaven \\ Our dead body and the shroud will reamin complete}

Do not be afraid of death since death is certain, but be afraid of the sins we have committed! When faith is strongly established, our spirits and souls will not get lost. God will miss us in His heaven. Our dead body will remain complete with our shroud.

In the description above, the syi'ir or poem clearly delivers a massage for readers or listeners to implement Divine values as a manifestation of their daily lives by maintaining harmony in life as a form of human characteristics as God creature, that is being depended on Allah SWT.

\section{Suluk as Human Metamorphic Process}

With the guidance of Allah, the salik (spiritual path taker) decides to penetrate into a diverse world. The wise call this journey as sayr wa suluk (spiritual journey). Suluk means to travel. Meanwhile, sayr means to look for outstanding characteristics and traits in a variety of practice such as self-restraint. This practice is needed in this spiritual journey. Because of the difficulty to break the material connection, the salik 
slowly unravels the snares of the pluralistic world carefully and starts the journey from the material world. ${ }^{23}$

Sufism explains that sharia is merely rules and the tarekat is the act of carrying out the sharia rules. If sharia and tariqa can be mastered, then the haqiqat is born which strives to fix the situation. Its ultimate goal is makrifat which is to know truly God and love Him. Prophet Muhammad SAW said: Sharia is my word, the tariqa is my deed and haqiqat is my behavior. ${ }^{24}$

The notion of suluk in Syi'ir Tanpa Waton is found in the ninth syi'ir verse, namely:

\author{
Kelawan Allah kang moho suci \\ Kudu rangkulan rina lan wengi \\ Ditirakati diriyadhahi \\ Zikir lan suluk jo nganti lali. \\ Meaning: \\ To the Most Holy God \\ We must join hands day and night \\ Performing self-restraint and riyadhoh \\ Remembrance of Allah and suluk, do not forget
}

In Javanese language, the word tirakat originally comes from the word tariqat / tarekat which lexically means 'road'. All tarekat teachings originate from and lead to the teachings of Sufism which are known as prophetic traditions. Tariqat teachings also place Nabi Muhammad SAW as the central point. The teachings of the tarekat refer to al-Qurân and Sunnah, and come from the method of suluk which was practiced by the Messenger of Allāh. The teachings are sourced from the Prophet through connected sanad, namely the genealogical system that continues to the Prophet Muhammad. ${ }^{25}$

In the view of the tariqat teachings, the spiritualization of Sharia practice is closely related to the wandering of the spiritual journey in the form of suluk. This step of wandering and spiritual journey can be simply described as someone who is looking for pearls in the depth of the ocean. Sharia, tariqat and haqiqat become absolutely essential since they are one system. Sharia is described as an ark or ship that serves as

\footnotetext{
23 Murtadha Muthahhari dan S. M. H. Thabathaba'i, Menapak Jalan Spiritual, Terj, (Bandung: Pustaka Hidayah, 1997), p. 75.

24 Mustafa Zahri, Kunci Memahami Ilmu Tasawwuf, p. 85.

25 Ummu Salamah, Sosialisme Tarekat Menjejaki Tradisi dan Amaliyah Spiritual Sufisme, p. x-xi.
} 
a tool to get to the destination. Tarekat is a very wide ocean where the pearl is. Haqiqat is the pearl that is sought by the salik and Sufi namely ma'rifat billah. ${ }^{26}$

The word riyadah comes from Arabic language which means exercise and practice. The exercise here means souls and feeling excercise that can only be carried out through the practice of the tariqat which is strictly guided by the tariqat teacher because the practice of the tariqat must be done gradually through mujahadah, tazkiyah an-nafs continuously. ${ }^{27}$

Dhikr is something important for humans to not forget themselves. In this sense, dhikr is used as a reminder for humans to always be aware of their existence as creatures of God.

Without $d h i k r$ and thinking, a human being will not be able to make the most of their benefits as a human. Without thinking and dhikr human will not be able to walk on earth in line with the mystical concept of humanity-Divine life. This awareness leads people to self-awareness and balanced life orientation which combines two aspects; developing powers and thinking abilities. ${ }^{28}$

The word suluk is from Arabic language with the root word salaka-yaslukusulukan which lexically means "walking, entering, passing through road, and acting. ${ }^{29}$ In KBBI suluk is interpreted ${ }^{30}$ : (1) a road toward inner perfection, Sufism, tariqat, mystical. (2) Self- alienation, seclusion, (3) song of a puppet performer when starting a scene (episode) in a puppet show.

Of the three meaning of mysticism, the most appropriate one for the context Syi 'ir Tanpo Waton is the first and second meaning; a road toward inner perfection, Sufism, tariqat, mysticism and self-alleniation or seclusion.

Riyadah, dhikr, suluk are terms for tariqat practice to draw closer to Allah so that they always come and stick together day and night, rangkulan rina wengine. Usually in suluk training place (zawiyah), there are various kinds of teachings, practices, ijazah, tawajuhan, etc. In short, the knowledge of spirituality (divinity) and the essence of spirituality can only be bridged through the path of the tarekat. Only do among the ahlu atāriq understand the meaning of dhikr and suluk. According to Guz

26 Ummu Salamah, Sosialisme Tarekat Menjejaki Tradisi dan Amaliyah Spiritual Sufisme, p. 78.

27 Ummu Salamah, Sosialisme Tarekat Menjejaki Tradisi dan Amaliyah Spiritual Sufisme,

28 Ummu Salamah, Sosialisme Tarekat Menjejaki Tradisi dan Amaliyah Spiritual Sufisme, p.159.

29 Ahmad Warsun Munair, Kamus Al-Munawir Arab-Indonesia Terlengkap, (Yogyakarta: Pustaka Progressif, 1997), p. 653.

30 Tim Penyusun Kamus Pusat Pembinaan dan Pengembangan Bahasa, Kamus Besar Bahasa Indonesia, p. 866 .

Teosofia: Indonesian Journal of Islamic Mysticism, Vol. 7, No. 2, 2018 
Nizam suluk itself is a journey back to Allah SWT by continuously doing holy war within ourselves to combat lust, disbelief, demons in the soul. ${ }^{31}$

In an Islamic study forum in East Java, Gus Nizam explained the urgency of suluk. One day in the Prophet era, the Prophet reprimanded a companion for being too proud of the victory achieved by Muslims in the battle of Badr. At that time, Muslims accounted for 313 persons with improvised weapons were capable of defeating the enemy with more than 10,000 armed forces. ${ }^{32}$

After the companions returned to Madinah, they were too proud of themselves, so they were teased by the Prophet Muhammad with the sentence "raja'nā min al-jihād al-asgar ila al-jihā $d$ al-akbar" which means we have returned from a small war to a bigger war. Hearing this the companions were surprised at once and asked, "Badr war is a very big war, how do you say it was small war, what do you mean, O Prophet?" The Prophet Muhammad said, "after this we must always wage a great battle, $O$ friends" they asked, "what war does the Prophet call a great war?", He said, "jihādunnafsi (war against lust)". To fight lust is to fight ourselves, our low souls, and to fight the qualities of devil, to fight the nature of shaytan, bahāimiyyah, hayawāniyyah, and the nature of our basyariyah so that what remains in us is only the insāniyyah, malakūtiyyah, rabbaniyyah. ${ }^{33}$

The person who walks on the spiritual path can be described as someone who built water storage in his house which has not been used for a long time. Meanwhile various impurities and stains had settled in the bottom of the tank even though the water looked clear from above. He thought that the water was clean but when diving into a tank or washing something in it, dirty and murky lumps rose to the surface and then he knew that the water was dirty. ${ }^{34}$

Guz Nizam in another occation explained the suluk process in the heart of each salik. The process follows the path of the Prophet in doing self-allienation in cave Hira before his prophecy to have peaceful mind, clear heart, and real probity amid the crowd of life and spiritual crisis occurring in the Jahiliyah community. Like a caterpillar, it must become a cocoon before turning into a beautiful butterfly. ${ }^{35}$ So do humans in the spiritual journey (holly tour) to God (suluk).

31 Interview with Mohammad Nizam As-Shofa the director of ponpes Ahlus Shofa-wal wafa, di Sidoarjo tanggal 18 Nov 2016.

32 The history of Syiir Tanpo Waton of K. H. Nizam As-Shofa being labelled as Syi'iran Gus Dur is found here: https://www.youtube.com/watch?v=7tHr8MwXeBY accessed on April 10, 2016.

33 The Asal usul Syiir Tanpo Waton K. H. Nizam As-Shofa di anggap Syi’iran Gus Dur. https://www.youtube.com/watch?v=7tHr8MwXeBY accessed on April 10, 2016.

34 Murtadha Muthahhari dan S. M. H. Thabathaba'i, Menapak Jalan Spiritual, Terj. hlm. 77.

35 Interview with Mohammad Nizam As-Shofa, PP. Ahlus Shofa Wal Wafa, at Sidoarjo on Mey 18, 2016. 
They must go through certain phases namely Takhalli (purgative) that is the toughest philosophical aspect due to its difficult effort of emptying and cleansing soul from the despicable qualities that can damage human's physics and mentality. The next one is Tahalli (contemplative) or meditation. It is the stage of filling the soul with the attributes of mahmudah (good and praised deed) after the soul is being emptied off despicable qualities. If a person can go through the two stages of Takhalli and Tahalli, he will reach the third stage, namely Tajalli (Illuminative). That is the process of revealing the insulating curtain of the unseen and the acceptance of the nur ghoib (unseen light) in the heart of someone ${ }^{36}$ who will be a holy human being. He will be illuminated by his soul and clean heart so that a person can have implications of harmonic social life.

Sufism does not always involve tariqat and not all tarekat involve suluk. But suluk itself must go through tariqat and tariqat must be sourced from Sufism. One is not obliged to enter a certain congregation of mysticism because there are many ways and spiritual paths to become a holy human being, a pious person who has akhlak alkanimah (good behaviour) or virtuous, as many as the number of humans and their humanity. But in Naqsabandiyah Khalidiyah Mujaddidiyah tarekat community in the Ahlus Shofa Wal Wafa (ASW) boarding school, as symbolically written in Syi'ir Tanpa Waton (STW), the tarekat teacher always builds conditions and living systems that everyone can advise each other to stay on the path to God. For this reason, the salik needs to focus his thoughts with the help of riyadah and various practices of selfrestraint so that his attention is not turned away from God.

\section{Kinds of Suluk}

Walking on the path heading to God is generally not due to compulsion but rather due to personal awareness. In other words, people entered the tarekat because of an inner whisper. Encouragement arises because of sincerity and sincerity arises from the heartstrings. Entering the realm of the spiritual path is actually very likely preceded by the exhaustion of the exploration of personal life to find the authenticity of complete religious truth. Obedience that comes from personal encouragement will in turn cause strong motivation to practice the teachings in a more disciplined and consistent manner in everyday life. They feel the need, sense, comfortability and happiness to walk the suluk. When they leave the practice they should do, they feel anxiety. Therefore they interpret the consistency of the practice of the tarekat as a commitment to always obey God. The Qur'an clearly states that whoever obeys Allah, Allah will give him unlimited solutions (makhrajan, way out of trouble) and unexpected rizki or fortune (min haisu la yahtasib). ${ }^{37}$

\footnotetext{
36 Totok Jumantoro dan Samsul Munir Amin, Kamus Ilmu Tasawuf, p. 229.

37 Ummu Salamah, Sosialisme Tarekat Menjejaki Tradisi dan Amaliyah Spiritual Sufisme, p. 168.
} 
Suluk is an effort to isolate self from the hustle and bustle of worldly affairs and problems. Seclusion or suluk also means living in community, but still maintaining a strong relationship with God. Some of the tarekat do not teach seclusion (khalwat) in the physical sense because the khalwat is sufficiently done in heart or qalb (khalwat bi al-qalb). Other tarekat teaches seclusion physically as a method of training to perform seclusion in heart or bi al-qalb. This teaching is carried out by taking i'tibar or wisdom from the history of the Prophet Muhammad SAW before his prophecy. ${ }^{38}$

Tarekat tradition's function is to create inspiration, motivation, meaning, and initiatives in order to further increase the contribution to spread islamic message of mercy or rohmah in the midst of current changes. Therefore, a tarekat practitioner must have an awareness of sociocosm, social wisdom, empathic, social concerns and sensitivity, and strive to free others from their entanglements and difficulties in life. The tarekat practitioners must be actively involved, committed and responsible in efforts to create welfare. ${ }^{39}$

Every practitioner of the tariqah must be fully aware of the progress of the spiritual life as suluk (seeker of God) and as salik (ascetic of the spiritual path). Suluk is interpreted as an effort to take the path to God. That is physical act and can be seen as a movement physically, while suluk is a spiritual journey that has certain stages, as follows ${ }^{40}$ :

1. Suluk Nafs is interpreted as soul purification, namely doing praiseworthy and malicious qualities after cleansing soul from despicable qualities and animal lust. In other words the self that has been cleansed of impurities and its damage is transformed into an-nafs al-muțma'innah (calm soul). So suluk is not a movement in the spatial dimension, but rather progress in the spiritual life; the spiritual progression from despicable qualities to good and praiseworthy qualities. This forward motion is another name for transmutation or normal inward changes in human beings.

2. Suluk Qalb or heart is interpreted as tas fiyah al-qalb or heart purification to eliminate the love to this mortal world, its concern for various kinds of sadness and sorrow, its tendency towards worldly matters, and all its grandiose thoughts that are vain.

3. Suluk sirr or the secret is a spiritual understanding called takhalliyah as-sirr or emptying sirr. This means that there is an attempt to empty the sirr of all kinds of thoughts which will distort it from remembering Allah or dhikr. This capability

38 Ummu Salamah, Sosialisme Tarekat Menjelajahi Tradisi dan Amaliah Spiritual Sufisme, (Bandung: Humanoira, 2005), p. 125.

39 Ummu Salamah, Sosialisme Tarekat Menjelajahi Tradisi dan Amaliah Spiritual Sufisme, p. 166.

40 Ummu Salamah, Sosialisme Tarekat Menjelajahi Tradisi dan Amaliah Spiritual Sufisme, p. 117. 
must be maintained in a way that the thought of anything other than God is not going to be able to get into sirr. If it appears, suddenly sirr should delete it immediately.

4. Suluk ruh or the soul, a mystical contemplative organ expressed as tajalliyah arruh or enlightenment of the spirit. This means that there is an attempt to fill the soul with a vision about God and the surge of mahabbah (love of Him). So suluk consists of purification of the heart, purification of the soul, emptying the sirr, and enlightenment of the spirit. The purpose of all these processes is av transformation or the formation of self-character by grounding in Divine moral and ethical character.

Furthermore, based on the information that the author got from Guz Nizam, suluk is divided into 2 categories. ${ }^{41}$ First is the small suluk or khalwat fil alkhalwat (seclusion in a quiet place) and the second is the great suluk or khalwat fil aljalwat ("seclusion" in a crowded place).

"There are two kinds of suluk, small and big suluk. Small suluk is the same as the term khalwat fi al-khalwat (seclusion in a quiet place). After small suluk (seclusion in a quite place), a practicioner of suluk should continue to great suluk. This big Suluk is kholwat fi al jalwat (seclusion in a crowded place) or "topo ngrame" in Javanese term. Essentially, topo was in the soul of each of us. This action is inspired by the Prophet before his prophecy, following the apostle before he was appointed as an apostle by Allah SWT. Because we all cannot follow the Prophet after he was appointed as a prophet, just as like we follow a successful employer, we cannot follow the employer after his success, but we must follow an employer's journey before he becomes a successful employer. Because we will have difficulties and objections following our employer who are already successful, so do we follow the Prophet Muhammadaa?" Said Gus Nizam.

\section{a. Small Suluk (khalwat fi al-khalwat)}

As Guz Wahab explained, this small suluk in the Ahlus-Shofa Wal Wafa Islamic boarding school was carried out for 10 days and 10 nights. During that time, a salik (a God path taker) must remain in their own place with constant remembrance and thinking of Allah and muraqabah except during the five daily prayers. Every salik must be able to feel the solitude as if they are in the grave. ${ }^{42}$ From small suluk, a salik must continue the journey to big suluk.

41 Interview with Mohammad Nizam As-Shofa the director of Ahlus Shofa-wal wafa, in Sidoarjo, 18 May 2016.

42 Interview with Abdul Wahab Machfudz, Khalifah (Guz Nizam' Vice) at Ponpes Ahlus Shofa Wal Wafa Sidoarjo on 18 May 2016.

Teosofia: Indonesian Journal of Islamic Mysticism, Vol. 7, No. 2, 2018 
Sufism does not mean to run away from real world life, as some people who disagree with Sufism have alleged, but Sufism is an attempt to equip ourselves with new spiritual values that will protect our selves when facing various problems.

\section{b. Great Suluk (khalwat fi al-jalwat)}

Staying quiet in the middle of the crowd (khalwat fi al-jalwat) Nyepi ing panggonan rame means that we must always present Al-Haqq(Allah SWT) in our heart. A Salik carries out activities such as socializing with others and still maintains heart in order not to be distorted by negative things in every situation either being alone or being in the middle of a lot of people. Salik's heart is disappearing (ghaib) from God's creatures even though his body was among them.

If the salik is busy with worldly life, so that he deliberately forgoes his wirid (a citation from the Koran which is read repeatedly as a way of asking for God's forgiveness, etc.), they will do the wirid in other occasions so that every tarekat practitioner (salik) always keeps the practice of the tarekat in an istiqomah (steadfastness) way, that is not limited by space and time. The effort to replace wirid in another time can not be separated from the belief that the wirid will always be lifted to heaven. The voice rumbled like the sound of wasps will continue to echo and be witnessed by angels, apostles, believers and God as one of the practices that will be accepted on the Day of Judgment. Therefore, the effort to do qada (fulfilling or completing those duties that one may have missed due to some reason or other.) has the same virtue and value as the practice of wirid on time. ${ }^{43}$

'Allamah Muhammad Husain At-Thabathaba'i added that there was no contraduiction between his walking through stages in suluk and his worldly basic needs. His inner experience is totally unrelated to his outward activities such as marriage, his activities for making a living and his involvement in trade or agriculture. The salik naturally lives in this world and engages in various worldly activities. But his soul penetrated the realm of Malakut and chatted with its inhabitants. Likewise, a person who walks in the spiritual path must fulfill his natural needs and at the same time, he maintains his relationship with God. ${ }^{44}$

It means that amids being busy doing his activities, he is able to keep his self stable. Therefore, he has realized what Umar ibn Khattab expected us to do namely being in the middle of society (socializing) but still keeping worship and prayers as Umar says “khālițu an-nas fi ma'ayasyikum wa zayyiluhum bia'mā likum”.

It can be concluded that suluk in Syi'ir Tanpa Waton consists of small suluk (khalwat fi al-khalwat) and big suluk (khalwat fi al-jalwat). Meanwhile, soul/nafs

\footnotetext{
43 Ummu Salamah, Sosialisme Tarekat Menjejaki Tradisi dan Amaliyah Spiritual Sufisme, p.169-170.

44 Murtadha Muthahhari dan S. M. H. Thabathaba'i, Menapak Jalan Spiritual, Trans. p. 118.
} 
purification and suluk qalbheart purification are called Takhalli (purgative) which is followed by emptying sirr or Tahalli (contemplative). The next path is ruh/spirit enlightmen or Tajalli (purgative); a process which should be done by doing small suluk and big suluk in Qalb (Takhalli/purgative) and emptying sirr (Tahalli/contemplative).

\section{STW Relevance for Present Context}

Modernity provides technology but at the same time it brings us mental crisis. This situation will cause bad effects for human in their increasingly complex lives. Several negative impacts of modern life arise in various forms including deviations of social behaviour, such as egoism, materialism, hedonism, consumerism, competition that ignores the societal and religious morality. In addition to that, some other modern problems are mental illness such as feeling depression, anxiety, uncertainty, loss of meaningful awareness of life and community atomization due to globalization. ${ }^{45}$

Modern society as referred by Harvey Cox in his book The Secular Cit, as quoted by Emirito P. Napcil is a society called The City namely a society that has become secular. The relationship between community members is no longer based on the principle of tradition or brotherhood, but many are based on pragmatic functional principles. The people feel free from religious control and the view of the metaphysical world. Furthermore, Cox explains and mentions several characteristics of modernization i.e desacralizaton of the world; the lost of sacred values of the world), the historization of human life (putting human life in the context of historical fact) and the relativization of meaning. ${ }^{46}$

For the Sufi, spiritual teaching is the main way to control lust. If the teaching of Sufism about the soul purification and noble character has been well implemented, then humans will become servants of God who bring peace in this universe (rahmatan lil ā 'lamīn).

Based on the above facts, it can be said that in this global era, we need to revive doctrines that contain the spirituality elements in the form relevant to the present conditions and situations to achieve noble character and clean soul. The expected character to realize is the imitation of God's character as the Prophet Muhammad said in his hadith, Takhallaqu bi akhlāqi al-allah, behave like God's behaviour .

This is reflected in the socio-religious activities that the researcher observed and experienced at the boarding school of Ahlus-Shofa Wal Wafa (ASW), their community prioritized attitude of empathy, conscientiousness, diligence and patience. They had more refinement and taste, aesthetics, and discipline. They also

\footnotetext{
45 Ummu Salamah, Sosialisme Tarekat Menjejaki Tradisi dan Amaliyah Spiritual Sufisme, p. 192.

46 Amin Syukur, Menggugat Tasawuf Sufisme dan Tanggung Jawab Sosial Abad 21, p. 112.
} 
stayed away from every form of violence and anarchism. They expressed respect, harmonious behavior, just, tolerant to differences of religions, customs, cultures and others. Those characteristics are the reflected from the frequent events held on the theme of interfaith fraternity attended by non-Islamic religious leaders.

Those activities are their implementations of the following syiir:

\author{
Kang anglakoni sekabehane \\ Alloh kang bakal ngangkat derajate \\ Senajan asor toto dhohire \\ Ananging mulyo maqom drajate \\ Meaning: \\ Let's just do everything \\ Allah will lift our degree (maqam)

\section{Although we look ugly in appearence \\ But noble in (maqam) degree}

Although outwardly in the eyes of human beings someone look low or despicable, but he essentially is noble and has high degree in the sight of Allah SWT. Senajan asor toto dhohire Ananging mulyo maqom drajate.

The teaching contained in the STW is still relevant for the present context. Its spiritual guide and social moral remain applicable for todays social life. It is because the meaning and function of the spirituality of Syi'ir without Waton contents is able to answer the crisis of meaningful life. It can purify heart and mind with a strong selfawareness. It will strengthen the ethos and caurage to always act actively and productively in worship, work and doing good deeds. This is well internalized as well as expressed in the socio-cultural behavior of the people. It can be seen from the growing honesty, trustworthiness, hard work, humility and love for others.

The teaching of suluk in the syi'ir is comprehensive Islamic teaching which focuses on the self-awareness of the adherents. Understanding and internalizing the teachings based on self-awareness will reflect on a person's behavior that can make him a social person and have a social awareness and attitudes, namely able to transform self-awareness (self-piety) to social awareness (social piety) into a perfect person (Insan Kamil).

A person who has reached the highest level of spirituality, has already had a lot of provision (by doing good deeds in the world) to meet Allah the khäliq. His life journey has found its way back to Him. In STW, provision for facing God occupies an urgent position reflected in verse 5 that says baguse sangu mulyo matine (the more the provision, the more noble the death). Implicitly this teaching of suluk teaches the importance of preparation of charity and worship before returning to God. So that 
the spirit or ruh is not lost in its journey to God because the spirit is accustomed to follow the road through the process of suluk that has been passed in the world.

Lastly, the closing syi'ir verse xiii says:

\title{
Lamun palastro ing pungkasane \\ Ora kesasar roh lan sukmane \\ Den gadang Allah swargo manggone \\ Utuh mayite ugo ulese
}

\author{
Meaning: \\ So in the end \\ Spirit and soul should not get lost \\ God promised heaven \\ Dead body and the shroud remain complete
}

The verse talks about death. Death is something everyone is affraid of or the other way around something that everyone is waiting for (cannot wait to meet God). One of the lines says "utuh mayite ugo ulese", ones' dead body and shroud remain complete. This is an ideal description of husnul khätimah death (good ending death). The offer of a good death will be gotten if a person does contents or advice in the syi'ir of STW.

\section{Concluding Remarks}

After analyzing and describing the content of isi Syi'ir Tanpa Waton, the researcher can draw conclusions as follows:

1. Broadly speaking, this syi'ir teaches all good manners and good deeds done by humans in the form of Javanese literature. The syi'ir is well structured. It starts from the meaning of not easily judging others as infidels, and the meaning of riyadhah, tarekat, dhikr, and suluk to achieve individual and social piety.

2. Suluk existing in Syi'ir Tanpa Waton is divided into two kinds, namely: small suluk (khalwat fi al-khalwat) and big suluk (khalwat fi al-jalwat). The first suluk is a process of human metamorphosis in which a person will feel urip ning jero mati lan mati ing jerone urip, living in death, dying in life and be reborn with a pure state of clean heart and mind. While the second one is the suluk in which his heart disappeared (ghoib) from all creatures althouh his physical body is among them. Both the two suluk happened in the process of suluk Qalb (Takhallipurgative) and emptying sirr (Tahalli/Contemplative).

Suluk in the present context is needed to set a peaceful mind to face negative impacts of modernization and spiritual crisis by doing seclusion both heart/qalb and body/jasad from the crowd. Seclusion is a symbol of taqarrub Ilallah (getting closer to 
God) to equip human with the spiritual values to not depend on anyone other than God Almighty. In the end, this process will result a calm, patient, active, productive person, and reinforce independence, consistency, integrity and identity. 


\section{Bibliography}

Siroj, Said Aqil. Tasawuf Sebagai Kritik Sosial, Bandung: Mizan. 2006.

Akbar, Muhammad Ali. Studi Tentang Suluk Dalam Tarekat Naqsyabandiyah Khalidiyah Aminiyah.

Ali, Yunasril. Membersihkan Tashawwuf Dari Syirik, Bid'ah Dan Khurafat, Jakarta: Pedoman Ilmu Jaya. 1992.

Berger, Peter L. Langit Suci Agama Sebagai Realitas Sosial terj. Hartono. Jakarta: LP3ES. 1991.

Braginsky. Yang Indah Berfaidah dan Kamal; Sejarah Sastra Melayu dalam Abad 7-9, Jakarta: INIS. 1998.

Bruinessen, Mratin Van. Tarekat Naqsabandiyah di Indonesia Survei Historis, Geografis Dan Sosiologis. Bandung: Mizan. 1992.

Jumantoro, Totok dan Samsul Munir Amin, 2005. Kamus Ilmu Tasawuf. Jakarta: Amzah.

Muhyiddin, Ahmad Shofi. Syiir Tanpa Waton Al-Maghfurlah K. H. Abdurrahman Wahid (Gus Dur), Yogyakarta: Ladang Kata. 2015.

Munawir, Ahmad Warsun. Kamus Al-Munawir Arab-Indonesia Terlengkap, Yogyakarta: Pustaka Progressif. 1997.

Muthahhari, Murtadha dan S. M. H. Thabathaba'i. Menapak Jalan Spiritual, Terj, Bandung: Pustaka Hidayah. 1997.

Nasr, Sayyid Husein. Spiritualitas dan Seni Islam, terj. Sutejo, Bandung: Mizan. 1993.

Nur, Edy Yusuf. Mengali Tasawuf yang hakiki, Yogyakarta: Suka Press. 2014.

Nur, Sayyid bin Sayyid Ali. 2000. Tasawuf Syar'i, Jakarta: Hikmah.

Panitia PIBSI XXIII UAD. Bahasa dan Sastra Indonesia Menuju Transformasi Sosial Budaya Abad XXI, Yogyakarta: Gama Media. 2002.

Putra, Erfandi. Syi'ir Tanpa Waton dan Sejarahnya, Sidoarjo: As-Shofa. 2015.

Roziq, Fahrur. Pondok Pesantren Ahlus-Shofa Wal Wafa Pengkaderan Dunia Akherat, Sidoarjo: As-Shofa. 2016.

Salamah, Ummu. Sosialisme Tarekat Menjejaki Tradisi dan Amaliyah Spiritual Sufisme, Bandung: Humaniora. 2005.

Teosofia: Indonesian Journal of Islamic Mysticism, Vol. 7, No. 2, 2018 
Sugiono, Sugeng. Bunga Rampai Bahasa Sastra dan Kebudayaan Islam, Yogyakarta: Fakultas Adab IAIN Sunan Kalijaga. 1993.

Syukur, M. Amin. Menggugat Tasawuf Sufisme dan Tanggung Jawab Sosial Abad 21, Yogyakarta: Pustaka Pelajar. 2012.

Tim Penyusun Kamus Pusat Pembinaan dan Pengembangan Bahasa. Kamus Besar Bahasa Indonesia. Jakarta: Balai Pustaka. 1989.

Zahri, Mustafa. Kunci Memahami Ilmu Tasawuf, Surabaya: Bina Ilmu. 1973.

\section{Interviews:}

Interview with Mohammad Nizam Ash Shofa, Chaiman and Cleric of PP. Ahlus Shofa Wal Wafa, at Sidoarjo, May, 182016.

Interview with Abdul Wahab Machfudz, Khalifah (Vice of Mohammad Nizam Ash Shofa) at PP. Ahlus Shofa Wal Wafa, Sidoarjo, on May, 182016.

\section{Internet:}

https://www.youtube.com/watch?v=Hu-fp6gKUZM accessed on April 10, 2016.

https://www.youtube.com/watch?v=eDdCnF6c4WA accessed on April 10, 2016. 